\title{
Topical Breastmilk Fasten the Process of Umbilical Cord Separation and Prevent Infection on Babies
}

\author{
Eni Subiastutik, S.Kep. Ns., M.Sc. \\ Lecturer in Health Polytechnic of Malang, Republic of Indonesia
}

\begin{abstract}
Umbilical cord infection is one of the highest causes of baby's deathin developing countries with high infant mortality rate. The umbilical cord may become the site for bacteria colonization that can cause infections such as omphalitis and neonatal sepsis. Umbilical cord care using milk containing anti-infective and anti-inflammatory topical can accelerate the separationtime of the umbilical cord and prevent infection in neonatal period. The purpose of this study to determine the effectiveness of breast milk topical administration compared to dry treatment in terms of the duration of umbilical cord separation.This study is a clinical trial with a randomized clinical trial design. The subjects were all newborns who met the inclusion criteria. The number of samples in this study was 64 newborns who were divided into two groups, 32 newborns in treatment group and 32 newborns in control group. Randomization was performed by using the technique of random allocation of block 6.Data analysis used univariate, bivariate test using independent t-test, and multivariate linear regression, with a confidence interval of $95 \%$ and a significance level of $p<0.05$.The result of this study shows that there are differences between the average amount of release time of the umbilical cord for those treated with topical ASI, which takes shorter length of time (5.69 days) compared to using dry treatment (7.06 days), with coefficient -2.11 and $R 2$ value is $0.67(67 \%)$. Multivariate analysis of umbilical cord care with incidence of local infection has a significant correlation that could be seen from $-2,51 \mathrm{sd} C I=-1.71$ and $p=$ 0:00. It can be concluded that the use of topical breast milk on umbilical cord care may accelerate its separation and lower the incidence of infection compared to the dry treatment method.
\end{abstract}

Keywords: topical breastmilk, dry care, time of umbilical cord separation

\section{Introduction}

During pregnancy, the fetus is passively highly dependent on the to grow. All substances needed by the baby were channeled through the placenta and is distributed by the umbilical cord. After the baby is born, the placenta and umbilical cord function as an active distributor will stop, and the baby will actively learn to suckle and attempt to activate their natural reflexes. When aiding baby delivery, cutting the umbilical cord, and care for the cord after the baby is born must be conducted in a very clean manner, as it is a port de entre of microorganisms that can cause neonatal infections, and develop it into sepsis. Clean care technique on clamming, cutting and tying the umbilical cord, as well as continuous umbilical cord care is the main principle that is very important to prevent the occurrence of sepsis due to the umbilical cord infection.

In developing countries, traditionalcord care usually done by using particular herb, a factor contributing to the incidence of neonatal tetanus and infection of umbilical cord. The incidence of sepsis is still the most common cause of morbidity and mortality in neonates. Research by Faridi et al. (1993) reported that $47 \%$ of infants who are hospitalized due to sepsis is suspected to get infection derived from umbilical cord. The newborns mortality rate in Indonesia is relatively high compared to other ASEAN countries. According to the Indonesian Demographic and Health Survey in 2002-2003, the infants mortality rate is 35 per 1.000 live births and the neonatal mortality rate is 20 per 1.000 live births. The main causes of neonatal mortality are low birth weight (LBW), asphyxia, tetanus neonaturum, and feeding problems. In order to accelerate the reduction in maternal mortality rate and infant mortality, the Ministry of Health has implemented a variety of programs related to maternal and child health and the prevention of tetanus on neonates. These efforts are carried out with the prevention of infection at delivery and cord care.

The data shows that maternal and infant mortality in Jember, East Java is quite high. A survey conducted by Kelompok Kerja Advokasi Kesehatan Ibu dan Balita (Eng: Advocacy for Mother and Child's Health) Jember, showed that in 100,000 births, at least 51 mothers died due to various reasons during delivery. Infant mortality in Jember mostly caused by Low Birth Weight (LBW) that is $27.7 \%$, because of the mothers' trauma during childbirth as much as $21.3 \%, 19.1 \%$ had an infection, and experiencing respiratory asphyxia as much as $6.4 \%$, congenital abnormalities factor as much as $10.6 \%$, and other factors $14.8 \%$, among others due to lack of nutrition and, immunization. At least there are three babies died of neonatal tetanus, most babies died aged 0 days to 28 days. Exclusive breastfeeding coverage rate is quite high, namely $90 \%$, but this time the usefulness of breast milk is still focused on infant nutrition only, and other functions are not yet known. 
Various attempts were made to reduce the occurrence of umbilical cord infection, which includes cutting the umbilical cord with a clean instrument, handwashing before and after handling the baby, baby bathing with antimicrobial agents and antimicrobial application on its umbilical cord. Breast milk contains leukocytes, proteolytic enzymes, and immunology substances which which helps to speed up the process of releasing the cord. Research about umbilical cord care with topical breast milk administration acceleratesthe separation time of the umbilical cord, which is an average of less than 7 days and it can also decrease the colonization of E. coli bacteria, Staphylococcusaureus, and Streptococcus group B 6, 7, 8. Cord separation is considered to be quick if it is less than 5 days, normal if it is between 5 to 7 days, and considered to be slow if it is more than 7 days. The results of community research in KwaZulu-Natal Kenya, the people are already familiar with the use of colostrum for umbilical cord care. Breast milk particularly its colostrum proved to contain bioactive substances including immunoglobulins, enzymes, cytokines, and cells that function effectively as antiinfective and anti-inflammatory. With various substances andbenefits, colostrum can be used as an alternative substance for umbilical cord care because it is quite sterile, cheap, readily available, and easily done by the mother.It is no doubt that breast milk is the best nutrition for infants. As an ideal nutrient, breast milk contains not only complete nutrients but also contains bioactive substances that have a protective function against infections due to microorganisms, hormones, and intermediate materials that regulate the immune system and anti-inflammatory components. The lysosim content in the milk is 300 times more than cow's milk, which is an enzyme that protects the baby against bacteria (E. coli and salmonella) and viruses. The white blood cells in the breast milk in the first 2 weeks is more than 4000 cells per mile. It consists of three kinds: Brochus-Asociated Lympocyte Tissue (BALT) antibody for respiration, Asociated Lympocyte Gut Tissue (GALT) antibody for respiratory tract, and Mammary Asociated Lympocyte Tissue (MALT) maternal antibodies for breast tissues.

With breastfeeding, the best start is given in the life of a child. It is estimated that more than one million children die every year of diarrhea, respiratory disease and other infections because they are not breastfed. Breastfeeding also helps protect the health of mothers.Based on the above background, the problem in this research can be formulated as: to which extent the effectiveness and safety of topical breast milk administration for umbilical cord care considered from the length of time of cord separation compared to dry care for infants.

\section{General Objective}

To find out the effectiveness of topical breast milk administration compared to dry treatment toward the cord separation length of time.

\section{Specific Objectives}

In particular, this study aims to:

1. Find out the average length of time of the umbilical cord separation by administering topical breast milk cord care and dry method care

2. Find out whether there is any incidence of umbilical cord infection with the use of topical breast milk care and dry method care

3. Analyze the effectiveness of topical breast milk administration compared to dry treatment care toward the separation length of time.

\section{Hyphotesis}

1. The average time of umbilical cord separation treated with topical breast milk is shorter than the dry treatment care.

2. Treatment with breast milk can reduce the occurrence of infection.

3. By administering topical breast milk then umbilical cord separation will be faster than by administering dry treatment care

\section{Framework}

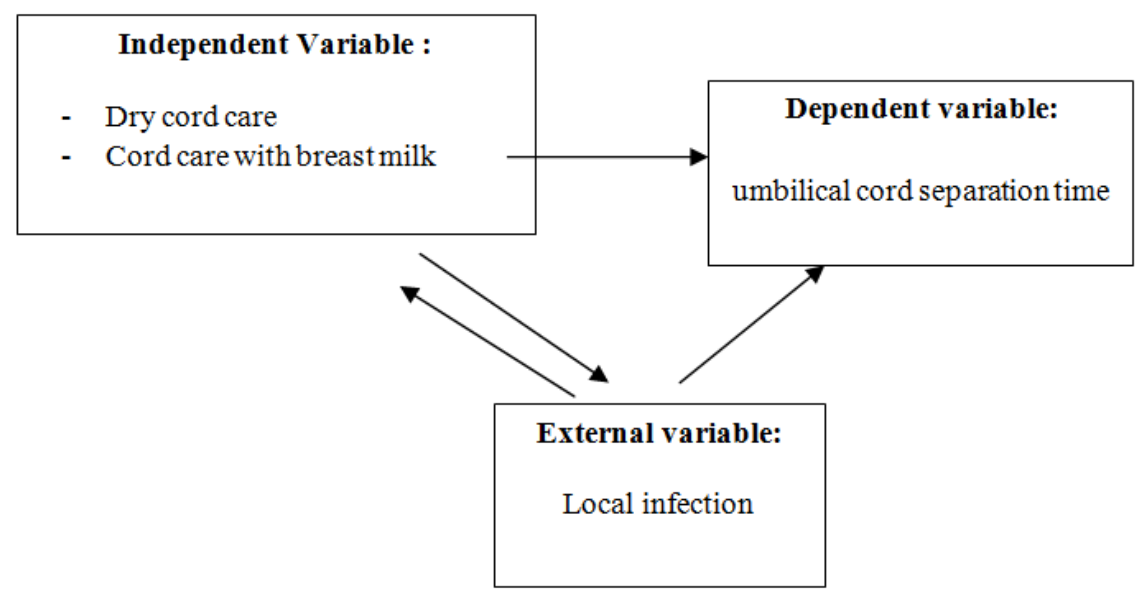

Figure 1.Framework 


\section{Method and Design}

This study is a clinical experiment with a randomized clinical study design. This study used two groups who received the treatment, in which group A (treatment group) are infants who received umbilical cord care with breast milk while group B (control group) are infants who received umbilical cord care with dry technique. Subjects in each group were randomized (Randomization Block 6). This study was conducted as an open clinical experiment as both the subject and the examiner aware about the actions taken.

The inclusion criteria are as follows;

1. Gestational age is $37-<42$ weeks

2. Weight of birth: $2500-<4000 \mathrm{~g}$,

3. The Apgar score of newborns: 7-10,

4. The infant's mother agreed to be the respondent.

The total number of samples was 64 subjects, 32 subjects for the experiment group and 32 subject to the control group.

The variables in this study are:

1. Independent variable is the umbilical cord care using dry cord care and topical breast milk

2. Dependent variable is the length of time for the umbilical cord to be separated in terms of the number of days and the sign of local infection at the umbilical stump.

3. External variable is the local umbilical cord infection, how to bathe the baby.

\section{Bivariate Analysis}

\section{Result and Discussion}

There are sixty four babies randomized in block 6 to obtain balanced two groups, 32 of them were treated with topical breast milk and 32 others with dry cord care. The frequency distribution of the characteristics of the subjects in both groups can be described in the table below.

Table 1: Demographic Characteristics of Both Research Subjects

\begin{tabular}{|c|c|c|c|c|}
\hline \multirow[t]{3}{*}{ Variables } & \multicolumn{4}{|l|}{ Groups } \\
\hline & \multicolumn{2}{|c|}{ Experiment } & \multicolumn{2}{|l|}{ Control } \\
\hline & $(n=32)$ & $\%$ & $(n=32)$ & $\%$ \\
\hline $\begin{array}{l}\text { Mother's age : } \\
<20 \text { years old } \\
20-35 \text { years old } \\
>35 \text { years old }\end{array}$ & $\begin{array}{l}4 \\
25 \\
3 \\
\end{array}$ & $\begin{array}{l}12.5 \\
78.13 \\
9.38\end{array}$ & $\begin{array}{l}3 \\
25 \\
4 \\
\end{array}$ & $\begin{array}{l}9.38 \\
78.13 \\
12.5 \\
\end{array}$ \\
\hline $\begin{array}{l}\text { Pariety : } \\
\text { - Primi } \\
\text { - Multi }\end{array}$ & $\begin{array}{l}16 \\
16 \\
\end{array}$ & $\begin{array}{l}50 \\
50 \\
\end{array}$ & $\begin{array}{l}13 \\
19 \\
\end{array}$ & $\begin{array}{l}40.6 \\
59.4 \\
\end{array}$ \\
\hline $\begin{array}{l}\text { Education: } \\
\text { - Low } \\
\text { - Mediocre } \\
\text { - High }\end{array}$ & $\begin{array}{l}8 \\
17 \\
7\end{array}$ & $\begin{array}{l}25.0 \\
53.1 \\
21.9\end{array}$ & $\begin{array}{l}8 \\
16 \\
8\end{array}$ & $\begin{array}{l}25.0 \\
50.0 \\
25.0\end{array}$ \\
\hline Bathing the baby frequency & 32 & 100 & 32 & 100 \\
\hline $\begin{array}{l}\text { Ways to bathe the baby: } \\
\text { - Using damp cloth } \\
\text { - In the water }\end{array}$ & $\begin{array}{l}4 \\
28\end{array}$ & $\begin{array}{l}12.5 \\
87.5\end{array}$ & $\begin{array}{l}3 \\
29\end{array}$ & $\begin{array}{l}9.4 \\
90.6\end{array}$ \\
\hline
\end{tabular}

Table 1 explains that the age of mothers in both groups is about 20-35 years of age. There are more multi parities and it is almost the same in both groups, while the education level is balanced in both groups that most of the mothers are at the level of secondary education, they want their babies to be bathed twice a day, and most of them bathe the babies by soaking them in water.

Table 2. Clinical Signs of Local infection for both Research Subjects

\begin{tabular}{|c|l|l|l|l|}
\hline \multirow{2}{*}{} & \multicolumn{2}{|c|}{ Topical breast milk } & \multicolumn{2}{l|}{ Dry treatment } \\
\cline { 2 - 5 } & $\mathrm{n}$ & $\%$ & $\mathrm{n}$ & $\%$ \\
\hline Dry /Not infected & 31 & 96.87 & 28 & 87.50 \\
\hline Signs of local infection : & & & & \multirow{2}{*}{12.50} \\
$\bullet \quad$ Rash & 1 & 3.12 & 4 & \\
$\bullet$ Swollen & 0 & 0 & 0 & \\
$\bullet$ Wet & 0 & 0 & 0 & \\
$\bullet$ With pus & 0 & 0 & 0 & \\
$\bullet$ Bad smell & 0 & 0 & 0 & \\
\hline
\end{tabular}


Table 2 describes umbilical cord condition after separation.Thegroup topical breast milk experienced local infection of $3.12 \%$, while the control group was more likely to have a local infection, with the percentage of $12.50 \%$.

\section{Bivariate Analysis}

Table 3: The Effect of Umbilical Cord Care, Infection, Bathing system compared to the Cord Separation Duration for Experiment and Control Group

\begin{tabular}{|c|c|c|c|c|c|}
\hline \multirow[t]{2}{*}{ Variable } & \multicolumn{5}{|c|}{ Cord Separation Duration } \\
\hline & $\begin{array}{l}\text { In Days } \\
(\text { Mean } \pm \text { SD) }\end{array}$ & $\Delta$ mean & t-count & C I $(95 \%)$ & $p$ \\
\hline Cord care with topical breast milk & $5.69 \pm 1.06$ & \multirow[t]{2}{*}{-1.37} & \multirow[t]{2}{*}{-4.12} & \multirow[t]{2}{*}{-2.06 to -0.71} & \multirow[t]{2}{*}{0.000} \\
\hline Cord care with dry treatment & $7.06 \pm 1.56$ & & & & \\
\hline No infection & $6.50 \pm 1.37$ & \multirow[t]{2}{*}{-2.11} & \multirow[t]{2}{*}{-3.37} & \multirow[t]{2}{*}{-3.36 to 0.86} & \multirow[t]{2}{*}{0.001} \\
\hline Local infection & $8.6 \pm 0.89$ & & & & \\
\hline Bathing way using damp cloth & $6.57 \pm 1.51$ & \multirow[t]{2}{*}{0.11} & \multirow[t]{2}{*}{0.16} & \multirow[t]{2}{*}{-1.07 to 1.27} & \multirow[t]{2}{*}{0.871} \\
\hline Bathing way by soaking in water & $6.67 \pm 1.46$ & & & & \\
\hline
\end{tabular}

Based on the bivariable analysis in Table 3, it shows that there are differences in the average length of time of umbilical cord separation which is treated by using topical treatment of breast milk and dry treatment, which accounts to - 1.37 . The statistical test shows the $\mathrm{p}$ value $<0.000$, so it can be concluded that there is a significant difference statistically between cord treated with topical breast milk in terms of the duration of umbilical cord separation, which is topical treatment using breast milk shows shorter duration compared to the dry treatment.There are differences in theduration of umbilical cord separation with local infection and no infection with the value of -2.11 . the statistical test result of $\mathrm{p}$ value $<0.001$, so it can be concluded that there is a significant difference between the incidence of local infection with umbilical cord duration separation, in which the average time of umbilical cord with infection is not shorter than those with infection. Meanwhile, there is no significant difference between how to bathe the baby and duration of cord separation with the average of 0.11 , and statistical test with $\mathrm{p}>0871$.

\section{Multivariate Analysis}

Table 4: Multiple Linear Regression Analysis; Free variables, Dependent variable to external variable.

\begin{tabular}{|l|l|l|}
\hline \multirow{2}{*}{ Variable } & Model 1 & Model 2 \\
& Koef & Koef \\
& CI 95\% & CI 95\% \\
& $p$ value & $p$ value \\
\hline Umbilical cord care; $\quad$ Topical breast milk care & -2.25 & -2.11 \\
$-\quad-2.70$ to -1.79 & -2.51 to -1.71 \\
$-\quad 0 \quad \quad$ Dry treatment & $0.000^{*}$ & $0,000^{*}$ \\
\hline Infection on umbilical cord & - & -1.41 \\
No infection & - & -2.20 to -0.63 \\
& & $0.001^{*}$ \\
\hline Adjusted $\boldsymbol{R}^{2}$ & 0.61 & 0.67 \\
Constanta & 7.78 & 9.02 \\
$\mathbf{N}$ & 64 & 64 \\
\hline
\end{tabular}

\section{Remarks :}

$\mathrm{p}=\mathrm{p}$ value

$\mathrm{R} 2$ = coefficient of determination

* = Significant

Model 2 was constructed by inserting the degree of influence of independent variableof cord care toward baby's umbilical cord separation, after including variable of local infection. The regression coefficient of cord care is -2.11. This shows that the umbilical cord care can accelerate separation time to 2.11 days, after inclusion of local infection variable. The value of this coefficient is reduced if compared with treatment coefficient prior to inclusion of local infection, but cord care variable remains significantly effective toward umbilical cord separation, with $p$ value $<0.05$. This model has a mean value of $R^{2}=0.67$ which means that after local infection variable is included it can affect a baby's umbilical cord separation time by $67 \%$. The process of umbilical cord separation is very complex, that is the drying and mummification process. The umbilical cord separation happens due to infiltration of nuclear polymorph leukocytes in the umbilical stump attached to the baby's stomach wall, and dryingprocess happens and maceration is formed. Breast milk contains leukocytes, proteolytic enzymes, and immunology substances, which helps the process of releasing the cord. Physiologically, umbilical stump will dry out and will usually detach itself. The duration of umbilical cord separation is considered to be quick if it is less than 5 days, it is normal if it is between 5 to 7 days, and slow if it is more than 7 days. 
According to WHO (1998), cord care is intended to prevent umbilical cord infection in premature neonates. Duration of umbilical cord separation is also affected by:

1) Humidity, the more often umbilical cord is exposed to the air, the faster is the mummification and cord separation.

2) Method of treatment and sanitation, by paying more attention to the hygiene of umbilical cord and our hands must be washed before and after caring for the umbilical cord, and it can prevent bacterial colonization.

3) Cord infection, which usually lengthening umbilical cord separation duration

Newbornbabies do not have normal flora on their skin. The baby's skin has a pH of 6.34 at birth and changed to 4.95 within 4 days for their colonization of the normal flora. Infection of the skin occurs because babies skin's $\mathrm{pH}$ balance is disrupted. Infection inhibits the drying process, mummification, and the cord separation. The umbilical cord is one of the body parts of infants with bacterial colonization.

Infection can also occur through the spread of microorganisms that enter through the wound tissues of the umbilical cord, and then enter the blood vessels and inflammation, thus becoming omphalitis even neonatal tetanus.

Wet or damp conditions, as well bad aseptic technique will lead to increasing colonization of pathogenic microorganisms, causing infection or neonatal tetanus. The longer the separation time, the more risks for infection. Some other factors that affect the duration of umbilical cordseparationis the incidence of infection on the umbilical cord, because some materials are applied to the umbilical cord such as ashes, soil, oil, leaves, coffee and so on. Non hygienic cord care facilitates the entry of pathogen bacterial that can disrupt the work of normal flora and $\mathrm{pH}$ changes in the skin around the umbilical stump, resulting in infection.

Non sterile baby delivery, unhygienic cord care, and applying medicinal herbsmay increase the occurrence of neonatal tetanus.

Epidemiologically and clinically, it is proven that in addition to being the primary nutrients, breast milk also contains; 1) The bioactive substances that provide protective functions for infants from pathogenic microorganisms, 2) hormones and growth factors that are important for the growth and development of infants, 3) materials that function to regulate the immune system, 4) anti-inflammatory components. Besides breast milk also contains anti-oxidants such as vitamin A, C, E, enzymes catalase, glutathione peroxidase, prostaglandin, platelet activating factor. Breast milk is very rich in white blood cells, or leukocytes, especially in colostrum. which is very protective, and has the ability to kill germs directly or indirectly 15 . This study indicate that treatment with topical breast milk fasten the duration of umbilical cord separation compared to dry care, as well as lowering the occurrence of local infection. Topical breast milk in particular its colostrum is rich in antibody substances, anti inflammation, and leukocytes which are all important to suppress the colonization of pathogenic microorganisms, which can cause infection of the umbilical cord, and accelerate duration of umbilical cord separation. All infants received breast milk so the baby gets colostrum's natural protection. Most baby are bathed by soaking in water, but this is not a humidity factor that can increase the colonization of pathogenic microorganisms, causing infection or neonatal tetanus and can lead to the longer duration of umbilical cord separation, as long as the baby is immediately dried up optimally in particular areas around the umbilical cord, also the cleanliness factor when the mother/family have contact with babies, that they should always washing hands before and after it, keep the area around the umbilical cord clean and dry. Maintain cleanliness, keeping the umbilical cord dry, will help to acceleratingumbilical cord separation with topical breast milk care, which is a very important factor as an effort to prevent umbilical cord infection. While the efforts made in infants with their local infection after the release of umbilical cord given Betadine as topical antimicrobial. According to WHO (1998), it is allowed to prevent further infection, such as sepsis and neonatal tetanus.

\section{Conclusion}

\section{Conclusion and Recommendation}

1. There is a significant difference in the time average of cord care with topical breast milk that is shorter than the dry treatment.

2. Localized infection is more common in cord care group using the dry method.

3. Umbilical cord care with topical breast milk will accelerate cord separation and lower the incidence of infection than the dry treatment method.

\section{Recommendation}

1. Treatment with topical breast milk can be recommended as a standard of care in newborns, since it has proven shorter average separation duration and it is better to prevent the occurrence of infection.

2. The nurse/midwife should take care of the umbilical cord using topical breast milk. 


\section{References}

[1]. World Health Organization. 1998. Care of The Umbilical Cord: A Review of The Evidence. Geneva: WHO.

[2]. Prawirohardjo, S. 2007. Ilmukebidanan. Jakarta: YBPSP.

[3]. DepartemenKesehatan RI. 2007. AsuhanPersalinan Normal. EdisiRevisi. Jakarta:.JNPKN.

[4]. DinkesKabupatenJember 2009. ProfilKesehatanKabupatenJember. Jember: DinkesKabupatenJember.

[5]. Mullany, L.C,, Darmstadt, G,. Khatry, S.K., Katz, J., Leclerq, S., Shresth, S.H., Adhikari, R. \&Tielsch, J.M. 2007. Risk factors for umbilical cord infection among newborns of Southern Nepal.Am J Epidemiol,165:203-211.

[6]. Farahani, L.A., Mohammadzadeh, A., Tafazzoli, M., Esmaeli, H. \&Ghazvini, K. 2008. Effect of topikal application of breastmilk and dry cord care on bacterial colonization and umbilical cord separation time in neonates.J of Chinese Clinical medicine, 6;3(6).

[7]. Janssen, P.A., Selwood, B.L., Dobson, S.R., Peacock, D. \& Thiessen, P.N. 2003. To dye or not to dye: a randomized, clinical trial of a triple dye/alcohol regime versus dry cord care. Pediatrics, 111:15-20.

[8]. Ahmadpuor, M.K., Zahedpasha, Y., Javadi, G.H. \&Talebian, H. 2006. The Effect of topikal of human milk, ethyl alcohol 96\%, and silver sulfadiazine on umbilical cord separation time in newborn infants. Archives of Iranian medicine, 9(1): 33-39.

[9]. Anderson, J.D. \& Philip, A.G.S. 2004. Management of the umbilical cord: care regimens, colonization, infection, and separation. Pediatrics, 5:e155-e163.

[10]. Hamosh, M. 2001. Bioaktive factors in human milk. PedatrClin N Amer, 48:69-86.

[11]. Sostroasmoro, S. \& Ismael, S. 2008. Dasar-DasarMetodologiPenelitianKlinis. Jakarta: SagungSeto.

[12]. Faridi, M.M., Rattan, A. \& ,Ahmad, S.H. 1993. Omphalitis Neonatorum. J Indian Med Assoc, 91:283-5.

[13]. Gallagher, P.G. \& Shah, S.S. 2010.Omphalitis.http//www.eMedicine.com. 14 Mei 2010.

[14]. Riordan, J,.Auerbach, K. 1999. Breastfeeding and Human Lactation. $2^{\text {nd }}$ ed. Massachusetts: Jones and BarlettPublisher :133-51.

[15]. DepartemenKesehatanRI . 2009. ManajemenLaktasi. Jakarta: Perinasia.

[16]. Cunningham, F.Gary., Gant, N.F, Leveno, K.J., Gilstrap III, L.C., Hauth J.C., \&Wenstrom, K.D. 2010.

[17]. Williams Obstetrics.Edisi 23:111-113;436.Jakarta: EGC.

[18]. Lemeshow, S., Hosmer Jr, D.W., Klar, J., \&Lwanga, S.K.1997.BesaranSampeldalamPenelitianKesehatanTerjemahanPramono, D. Yogyakarta: GadjahMada University Press.

[19]. Machin, D. \&Champbell, M.J. 2005.Design of Studies for Medical Research.:John Wiley \& Sons.

[20]. Medves JM, O;Brien B.A. 1997. Cleaning Solution and Bacterial Colonization in Promoting Healing and Early Separation of the Umbical Cord in healthy newborn.J Public Health, 88:380-382.

[21]. Medves JM, O;Brien B.A. 2001. Does Bathing Newborns Removes Potentially Harmfull Pathogens from the

[22]. Skin?J Public Health, 28: 1;61-65.

[23]. Minkes, R.K. \& Stephen, M.M. 2010.Disorders of the umbilical.http//www.emedicine.com.11 Juni 2010.

[24]. Mullany, L.C,, Darmstadt, G,. Khatry, S.K., Katz, J., Leclerq, S., Shresth, S.H., Adhikari, R. \&Tielsch, J.M. 2006. Topikal application of chlorhexidine to the umbilical cord for prevention of omphalitis and neonatal mortality in southern Nepal:a community-based-cluster-randomized trial. Lancet, 367:910-918.

[25]. NourianManigheh ,AllaiiFatemeh , HeidariAliehsan 2000. Comparison of the effect of Alcohol70\% versusdry cord care on cord bacterial colonization andcord separation time among newborns. Pakistan Journal of Medical Sciences, 25(1):103-107.

[26]. Novak, A.H., Muller, B. \& Ochs, H. 1998.Umbilcal cord separation in the normal newborn. Am J Dis Child, 142:220-3.

[27]. Sumaryani, Sri. 2009. PelepasanTaliPusatdan Omphalitis kajianterhadapPerawatandengan Air Susulbu, Alkohol 70\% danTeknikkeringTerbuka.Mutiaramedika:9(1);42-49.

[28]. Vural, G. \&Kiza, S. 2006. Umbilical cord care: a pilot study comparing topikal human milk, povidone-iodine, and dry care. $J$ Obstetrics Ginecologic and Neonatal Nursing, 35:123-128.Widowati, T. 2003.

[29]. EfektivitasdanKeamananKolostrumuntukPerawatanTaliPusat.Tesis.Yogyakarta:BagianIlmuKesehatanAnakFakultaskedokteranGad jahMada.

[30]. World Health Organization (2002) KonselingMenyusui: PelatihanUntuk Tenaga Kesehatan. WHO/CDR/93.4; UNICEF/NUT/93.2.

[31]. Zupan, J., Garner, P. \& Omari, A.A.A. 2009. Topikal umbilical cord care at birth Review.The Cochrane Collaboration, issue I. 